\title{
Muscarynic metabotropic receptor M4 modulates the hippocampal CA1 LTP possibly through local GABAergic interneurons
}

\author{
Querusche K Zanona1", Flávia Z Boos ${ }^{1}$, Ana Paula Crestani', Johanna M Duran ${ }^{1}$, Maria E Calcagnotto ${ }^{1,2}$, \\ Jorge A Quillfeldt ${ }^{1,3}$ \\ From The Twenty Third Annual Computational Neuroscience Meeting: CNS*2014 \\ Québec City, Canada. 26-31 July 2014
}

Muscarinic Cholinergic receptors of the subtype M4 are $\mathrm{G}$ protein coupled receptors that activate $\mathrm{Gi}$ reducing AMPc concentration on the cell and closing $\mathrm{K}^{+}$channels, causing hyperpolarization of the cell membrane and reduction of neurotransmitter release [1]. Previous works from our laboratory using the very selective Muscarinic Toxin 3 (MT3) to block M4 receptors showed that infusion of this substance into the dorsal hippocampus impairs memory consolidation [2] and facilitates memory retrieval [3], suggesting an important role for M4 modulation of CA1 circuitry in memory processes. Also, local application of this toxin in hippocampal slices was able to impair long-term potentiation (LTP) [4]. One hypothesis raised to explain these findings suggests that plastic changes taking place in the CA1 circuitry involves differential control of local excitatory cells and inhibitory interneurons. Since changes in LTP can be elicited by different mechanisms, the objective of this work was to verify, through an analog of the pharmacological infusion used in the behavioral studies, the effect of MT3 on LTP and the activity of inhibitory interneurons as possible targets of this cholinergic action.

Thus, we recorded fEPSP from Schaffer collaterals at hippocampal CA1 area of rats anesthetized under urethane. After setting the position and the stimulation intensity to obtain $50 \%$ of maximum fEPSP, we recorded $10 \mathrm{~min}$ baseline followed by drug infusion $(0.5 \mu \mathrm{l}, 20 \mu \mathrm{l} / \mathrm{h})$ through a delicate cannula glued to the recording electrode at the contralateral side of stimulae. We infused either MT3 $(2.0 \mu \mathrm{g})$, baclofen $(0.1 \mu \mathrm{g})$, MT3+baclofen

\footnotetext{
* Correspondence: querusche@gmail.com

'Neuroscience Graduate Program, Universidade Federal do Rio Grande do Sul, Porto Alegre, RS, 90040-060, Brazil

Full list of author information is available at the end of the article
}

(same doses), or their vehicles. After $15 \mathrm{~min}$, we applied a high frequency stimulation (HFS) protocol (10 trains at $0.5 \mathrm{~Hz}$ of 20 pulses $100 \mathrm{~Hz}$ ) and recorded the fEPSP for at least $90 \mathrm{~min}$. None of the treatments affected the baseline excitability.

Our results indicate that: MT3 infusion $15 \mathrm{~min}$ before HFS was able to block LTP, consistent with our previous finding with MT3 applied 2min before HFS [4], and baclofen, a $\mathrm{GABA}_{\mathrm{B}}$ receptor agonist in a subeffective dose, was able to prevent this MT3 effect. Considering that hippocampal $\mathrm{GABA}_{\mathrm{B}}$ receptors are mainly presynaptic and mostly located in GABAergic interneurons, and that its activation leads to cell hyperpolarization / reduction of GABA release, our results suggest that the M4 receptors relevant to those behavioral responses may be colocalized with $G_{A B A}$ receptors in the CA1 interneurons. Further studies are necessary to verify this hypothesis.

\section{Authors' details \\ ${ }^{1}$ Neuroscience Graduate Program, Universidade Federal do Rio Grande do Sul, Porto Alegre, RS, 90040-060, Brazil. ${ }^{2}$ Biochemistry Department, \\ Universidade Federal do Rio Grande do Sul, Porto Alegre, RS, 90035-003, Brazil. 'Biophysics Department, Universidade Federal do Rio Grande do Sul, Porto Alegre, RS, 90540-000, Brazil.}

Published: 21 July 2014

\footnotetext{
References

1. Sánchez $G$, Colettis $N$, Vázquez $P$, Cerveñansky $C$, Aguirre $A$, Quillfeldt JA, Jerusalinsky D, Kornisiuk E: Muscarinic inhibition of hippocampal and striatal adenylyl cyclase is mainly due to the $\mathrm{M}(4)$ receptor. Neurochem Res 2009, 34(8):1363-1371.

2. Ferreira $A R$, Fürstenau $L$, Blanco $C$, Kornisiuk E, Sánchez G, Daroit D, Castro eSilva M, Cerveñansky C, Jerusalinsky D, Quilfeldt JA: Role of hippocampal M1 and M4 muscarinic receptor subtypes in memory consolidation in the rat. Pharmacol Biochem Behav 2003, 74(2):411-415.
} 
3. Diehl F, Fürstenau de Oliveira L, Sánchez G, Camboim C, de Oliveira Alvares L, Lanziotti VB, Cerveñansky C, Kornisiuk E, Jerusalinky D,

Quillfeldt JA: Facilitatory effect of the intra-hippocampal pre-test administration of MT3 in the inhibitory avoidance task. Behav Brain Res 2007, 177(2):227-231

4. Sanchez Gonzalo, de Oliveira Alvares Lucas, Oberholzer Maria Victoria, Genro Bruna, Quillfeldt Jorge, Costa da Costa Jaderson, Cerveñansky Carlos, Jerusalinsky Diana, Kornisiuk Edgar: M4 Muscarinic Receptors Are Involved in Modulation of Neurotransmission at Synapses of Schaffer Collaterals on CA1. Journal of Neuroscience Research 2009, 87:691-700.

doi:10.1186/1471-2202-15-S1-P63

Cite this article as: Zanona et al:: Muscarynic metabotropic receptor M4 modulates the hippocampal CA1 LTP possibly through local GABAergic interneurons. BMC Neuroscience 2014 15(Suppl 1):P63.

Submit your next manuscript to BioMed Central and take full advantage of:

- Convenient online submission

- Thorough peer review

- No space constraints or color figure charges

- Immediate publication on acceptance

- Inclusion in PubMed, CAS, Scopus and Google Scholar

- Research which is freely available for redistribution

Submit your manuscript at www.biomedcentral.com/submit
C Biomed Central 